\title{
TEACHING METHODS IN PESANTREN TO TACKLE RELIGIOUS RADICALISM
}

\author{
Taufik Abdillah Syukur \\ Universitas Islam Negeri Syarif Hidayatullah Jakarta \\ Jl. Ir. H. Juanda, Ciputat, Kertamukti, Ciputat, Indonesia, 15412 \\ Email: taufik.a@uinjkt.ac.id
}

Received: 10, 2019. Accepted: 12, 2019. Published: 12, 2019.

\begin{abstract}
Religious radicalism has been a problem and a burning issue in social religion life in Indonesia. Government and the society including educational institutions like pesantren need to collaborate to solve this problem. This study was aimed at investigating the teaching methods applied in pesantren as an effort to tackle religious radicalism. This research used descriptive qualitative method. Techniques used were observation, interview and documentation. Interview was done to several key informants from pesantren to gather relevant information. The results showed that pesantren around the capital city of Jakarta still applied learning methods namely sorogan, bandongan, Islamic classic book reading. Those methods were designed to promote discussion in learning Islamic material. In addition, the learning methods developed santri academic achievement nurture their social skills. Given these skills and competencies, santri were taught to respect opinions of others and promote the effort to tackle religious radicalism in pesantren.
\end{abstract}

Keywords: Pesantren, Religious Radicalism, Teaching Methods

\begin{abstract}
ABSTRAK
Radikalisme agama menjadi masalah dan isu yang panas dalam kebidupan social keagamaan di Indonesia. Pemerintah dan masyarakat termasuk institusi pendidikan seperti pesantren perlu melakukan kolaborasi untuk menyelesaikan masalah ini. Penelitian ini bertujuan untuk menginvestigasi method pembelajaran yang dilaksanakan di pesantren dalam menangkal pemahaman keagamaan radikal. Penelitian ini menggunakan metode deskriptif-kualitatif. Teknike yang digunakan untuk. mengumpulkan data adalah observasi, interview dan studi dokumentasi. Wawancara dilakukan kepada beberapa informan kunci di beberapa pesantren. Hasil penelitian menunjukan bahwa metode pembelajaran yang digunakan oleh pesantren termasuk metode, sorogan, bondongan ngaji kitab kuning. Metode-metode tersebut didesain untuk mempromosikan diskusi dalam pembelajaran materi keislaman. Selain itu, metode tersebut mengmbangkan kemampuan akademik dan memperkuat keterampilan sosial mereka. Dengan keterampilan dan kompetensi yang dimiliki, santri diajarkan untuk. menghormati pendapat orang lain dan juga menjadi kebiasaan untuk. mebentuk. upaya-upaya melwan radikalisme beragama.
\end{abstract}

Kata Kunci: Pesantren, Radikalisme Beragama, Metode Pembelajaran

\section{INTRODUCTION}

Pesantren (Islamic Boarding School) is one type of religious education institutions in Indonesia. This Islamic educational institution has a strong cultural root in Indonesian community. Therefore, the existence of pesantren in Indonesia has a great influence for the surrounding community where pesantren exists. Speaking of religious education, the influence of pesantren is unquestionable because its establishment was indeed prepared to educate and spread Islamic teachings to the public (Wahyoetomo, 1997). The presence of pesantren in the community has not only serves as an educational institution but also as a religious institution. During the colonial period, it was the most closely related educational institution to the people. This is to 
say that pesantren served Islamic educational institution which was familiar for people especially those with low- income families (Mastuhu, 1994).

Pesantren, seen from its founding objectives, include: elevating the morale and spirit of the santri, respecting spiritual values and human values, teaching honesty, and preparing santri for a simple life. Pesantren, according to Zamaksyari Dhofir (1983), Bahri (2018) does not teach the struggle for power, money and prestige that are of a regular nature. The mission of pesantren is devotion to God as the final destination. Judging from the dimensions of the pesantren's purpose, people are born with high moral standards, polite, honest, and not radical. However, lately, there has been a public stigma about the existence of pesantren as an institution that teaches religious radicalism to students. The negative stigma of the community towards pesantren is reinforced by the statement of Jusuf Kalla, Vice President of the Republic of Indonesia, that pesantren need to be closely monitored. Jusuf Kalla believes that radicalism, one of the indicators of the Bali bombing, was allegedly committed by santri or former santri. (Ridwan, 2019; Irsyadunnas, 2018)

Some pesantren institutions are deemed as the educational institutions which support the hard-line understanding in realizing their religious teachings and they act intolerant. In the context of radicalism, the actors are the one who develop discourse of radicalism and who are mostly educated from pesantren institutions and constantly promote radicalism. In response to this, the society have expressed their concern and perceived that pesantren insttutions as a place of education for potential terrorists. The issue of radicalism which are closely linked to pesantren institutions has made the image of pesantren worse (Nuhrison, 2010; (Ferdian \& Mustofa, 2019)

Pesantren in this era has been extensively penetrated and bombarded by the advance of information and communication technology. They are also challenged socio-economically to play a role in the society especially those institutions that are located in and near the capital city of Jakarta. They are challenged both to prove that they are not radicalism supporter and to provide the best response to deal with religious radicalism. They should uphold the motto to maintain good old ways and to adopt and develop new ways that are better (Mahfudh, 1999). They have many options to tackle religious radicalism and one of them is to transform teaching methods to suit their students to tackle religious radicalism.

Several studies on the issue of radicalism among pesantren have been investigated. Alfanani (2017) reported social community construct on radicalism issue in Malang. Researcher have reported on the potential of pesantren for radicalism (Jahroni, 2007). Radicalism has also been associated with several factors. Education culture in pesantren can be associated with radicalism (Malik et.al.., 2016). In the same vein, pesantren education pattern may contribute to radicalism. Pesantren in this context are no longer agents of change, but purify (Mursalin \& Kasir, 2010). A study also reported how salafiyah influenced students' perception on radicalism (Taufiq \& Kholilur, n.d).

Some researchers have reported the effort and program applied by pesantren to fight radicalism. Alfanani (2017) reported pesantren in Malang and its effort to fight radicalism. Bahri (2018) and other researchers have also investigated pesantren effort to fight radicalism in several regions, pesantren in Rejang Lebong: pesantren in Lampung (Budi \& Chintya, 2017); pesantren in Mojokerto (Laksono, 2017); pesantren in Kediri (Ferdian \& Mustofa, 2019); pesantren in northern coast area of Java, Lamongan (Ridlwan, 2019); and pesantren in Semarang (Maarif, 2014). There is a need to conduct study on pesantren institutions' effort to tackle religious radicalism in West Java. The purpose of this study was to determine the teaching methods applied in several pesantren institutions located in West Java in their effort to tackle religious radicalism. 


\section{METHOD}

This research was qualitative in nature and it applied descriptive method. Descriptive research is carried out with the main objective, namely to systematically describe the facts and characteristics of the object or subject being studied appropriately (Sukardi, 2003). Data were collected using observation, documentation, and focus group discussion (FGD). The data were analyzed through some steps: reduction, categorization and interpretation.

\section{RESULTS AND DISCUSSION Religious Radicalism}

Radicalism comes from the word "radical", which means: 1) Overall, all-out, radical change; 2) Very strongly demands changes (laws, government, and so on); 3) Advance in thinking and acting. It can also mean: 1) Radical ideology or flow in politics; 2) Understanding or flow who wants social or political change or renewal in a hard or drastic way; 3) The extreme attitude in a political school. Meanwhile, the 'ism' affix itself has the meaning of an understanding or belief (Poerwadarminta, 2002). According to (Azra, 2002), radicalism is the attitude of the soul that leads to actions aimed at weakening and changing the established political order and usually using violence and replacing it with a new system (Azra \& AlJauhari, 1996). The word religion refers to "a system that regulates the rules of faith (belief) and worship of Almighty God and the rules relating to the association between humans, as well as humans on the environment" (Poerwadarminta, 2002).

Religious radicalism as a perspective, ideals, and attitudes can be individual and group. Individual religious radicalism is common in every religion to fully believe in the teachings of his religion. However, if religious radicalism is group in nature, it is not uncommon to become an ideology that perpetrates violence and resistance (Laksono, 2017). Radical groups have several characteristics, according to Yusuf Qarḍāwī, among others; First, it often claims a single truth and misleads other groups who disagree. Second, radicalism complicates the religion of Islam which is actually a mild religion, by considering the Sunnah worship as if it is obligatory and makrüh as if it is haram. Third, radical groups are mostly excessive in practicing religion. Fourth, radical group usually are rude in interaction, loud in speaking and emotional in preaching. Fifth, radical groups usually express prejudice toward others outside their group. Sixth, it is easy to disbelieve others who have different opinions (Purwaningrum, 2019).

Yusuf Qardāwi $\overline{1}$ argues that radicalism is caused by a number of factors: First, religious knowledge that is halfway through a doctrinal learning process; Second, it is literal in the understanding of religious texts so that radical people only understand Islam from their surface not the essence. They have limited insight into the essence of religion; Third, indulging in secondary issues such as moving your fingers during tasyabud, extending the beard, and lifting the pants while forgetting the primary problems; Fourth, it is excessive to ban many things that burden the people; Fifth, their perspective are so weak in historical and sociological insights so that their fatwa often contradict the well-being of the people, common sense, and spirit of the times; Sixth, radicalism rarely appears in response to other forms of radicalism such as radical secularist attitudes that reject religion; Seventh, they usually fight against social, economic, and political injustice at the heart of society ( Qarḍāwī, 2003).

\section{Teaching Method}

Etymologically the word method comes from Greek namely meta and hodos. Meta means through and hodos means way or way (Ramayulis, 2008a). In Arabic it is known as al-tharîq, meaning road. The road is something that is traversed to get to its destination (Nizar \& Hasibuan, 2011). The method refers to an orderly method used to carry out a job to be achieved by what is desired or systemic work methods to facilitate the implementation of an activity. To achieve what has been determined, someone has to achieve a certain goal, both in 
the environment or commerce or in connection with science and others (Fitriani \& Sundawa, 2016; Purwaningrum, 2019).

The word teaching can be interpreted as an effort to provide cognitive insight to students to foster affective and psychomotor abilities in students. Teaching is more a tool to enrich insight and foster true appreciation and practice. A true and solid appreciation and experience must be accompanied by correct understanding and insight and generated through teaching activities. This will happen if the teaching is done correctly, effectively and efficiently, and is aimed not solely at understanding a concept or theory, but is continued by living and practising it (Nata, 2000). Teaching methods are the methods used by teachers in establishing relationships with students during the learning process. Thus, the teaching method is a tool to create a learning process. This is in line with Edgar Bruce Wesley's who states that the teaching method is a series of directed activities for teachers that cause the learning process to occur in students, or it is a process whose implementation is perfect so as to produce a learning process, or it is a way by which teaching becomes memorable (Ramayulis, 2008).

In general, learning methods applied in pesantren include two aspects, namely: first, the traditional method, namely the learning method that is held according to the custom that has long been implemented at the pesantren or can also be called the original learning method (original) pesantren. Second, modern learning methods, namely the learning methods resulting from the renewal of the pesantren by incorporating methods that develop in modern society, although not followed by implementing a modern system, such as the school system or madrasa.

Multicultural education needs to be applied in pesantren education as an effort to provide understanding to students that they must be respectful of each different beliefs and even each cultural character with each other in order to create a harmonious atmosphere and tolerance in the education system in Indonesia (al-Hamdani, 2005).

To achieve this, the teacher must be introduced to several teaching methods, including 1) the method of contribution, in the application of this method students are invited to participate in understanding and appreciating other cultures. Namely, among others, by involving students to choose joint reading books, doing joint activities, appreciating religious and cultural events contained in social life. 2) enrichment method, this method enriches the curriculum with literature from or about people with different cultures and religions. For example, by inviting students to assess or test and then appreciate the perspective of the original Sundanese community about marriage. 3) the transformative method, this method is used to encourage students to understand issues and problems from several ethnic and religious perspectives. For example, discussing the concept of halal food from certain religions or cultures that have the potential to cause conflict in the community. This method requires students to process critical thinking and make the principle of diversity as their basic premise. 4) The method of decision making and social action, this method integrates the method of transformation with real activities in the community, which in turn can stimulate social change. Students are not only required to understand and discuss social issues but also to do something important in this regard. For example, after discussing conflicts over the construction of places of worship, students send letters to the local government or the mass media to express their opinions on related issues and government policies (CummingMcCann, 2003).

\section{Pondok Pesantren}

The term pesantren comes from the word "santri", where the word "santri" means students in Javanese. The term pondok comes from fundûq, which means lodging. Specifically, in Aceh, pesantren is also called the dayah. In west Sumatra, it is known as surau. Usually, pesantren is led by kyai. To regulate the life in pesantren, kyai appoints senior students to 
arrange for their juniors. The purpose of students being separated from their parents and families is for them to learn to live independently.

Pesantren is also defined as students. Its word comes from "the cantrik" word (Sanskrit, or maybe Javanese) which means people who always follow the teacher, which is then developed in a boarding system called Pawiyatan. The term students also exist in Tamil, which means the teacher recites. C. C Berg argues that the term comes from the term Shastri, which in Indian means a person who knows the sacred books of Hinduism or a scholar of Hindu scripture. Sometimes it is also considered a combination of the word "saint" (good human) with the syllable "tra" (like helping) so that the word pesantren can mean a place of good human education (Dhofier, 1983).

In pesantren, students stay together and study under the guidance of the teacher and they have a dormitory to stay. They are in a complex that provides a mosque for worship, space for learning, and other religious activities. The complex is surrounded by a wall to be able to oversee the entry and exit of students by applicable regulations. Pesantren, according to the basic understanding, is a place of learning for students, while pondok means home or residence. The kiai taught Islamic religious knowledge to students based on books written in Arabic by the Middle Ages Ulama.

\section{Pesantren Institution Profiles}

This research was conducted at several pesantren. Those pesantren institutions are located in several regions supporting the capital cities of Jakarta. Those regions include Bogor, Depok, Tangerang and Bekasi. Those pesantren institutions have their home base in those regions. The Lists of pesantren involved int his study are as follows:

First, Pesantren Darul Muttaqien which is located at the Jakarta Bogor highway KM 41 Jabon Mekar Parung Bogor West Java. This pesantren is led by Drs. KH. Mad Rodja Sukarta is under the Darul Muttaqien foundation with notarial deed No. 5 on 18 February 2003. It was established in Bogor on 8 July 1988 with an area of 31 hectares. The current number of students is 2049 students and the number of teachers is 272 teachers. Currently, the Darul Muttaqien Foundation houses several institutions, including RA, TPQ, DINIYAH, SDIT, SMPIT, MTs, MA, Care (dormitory) and Learning Resource Center.

Second, Pesantren Assalamah which is led by KH. Drs. Bahrudin Toyib, MM.Pd. It is under the auspices of the Assalamah Islamic Education Foundation addressing at Jalan Pesantren Assalamah Bojong Pondok Terong, Cipayung subdistrict, Depok, West Java 16444. In addition to the pesantren, the foundation has institutions including RA, TPQ, SDIT, SMP Islam and Vocational Business and Multimedia.

Third, Pesantren al-Karimiyah which is led by Dr. KH. Ahmad Damanhuri addressed at Jalan H. Maksum No. 23 Sawangan Baru, Depok City, West Java 16511. It was founded in 1990. In 1993, MTs was established one year ago in 1994 when they established the MA when forming the Hajj Guidance Group (KBIH). In 1998 al-Karimiyyah Islamic High School (STAISKA) was established and in 2000 run pesantern economic cooperation (Kopontren).

Fourth, Pesantren Asy-Syahidiyah which is led and founded by Ust. H. Sarwani Hasyim. This institution is located at Jalan Tegal Kadu Serang Batu, Bekasi Regency, West Java Province. This pesantren applies a combination between pesantren and national curriculum education. Like other pesantren institutions, this pesantren focuses on teaching Islamic education for its students.

Fifth, al-Hassan's modern pesantren. It has an area of 9,131 M2 has waqf status from $\mathrm{Mr}$ H. Hassan Al-Idruss. It was established on February 27, 2004, and is currently led by Prof. Dr $\mathrm{KH}$. Ahmad Satori Ismail. The number of students is approximately 282 people starting from junior high school level. It is located at Jl. Jambu RT/RW: 003/011 Behind the Jati Makmur Post Office Pondok Gede Bekasi West Java. 
Sixth, Pesantren Hidayatunnajah which is located at Jl. Pebayuran KM. 08 Desa Kertasari Subdistrict Pebayuran Bekasi Regency West Java 17710. The pesantren was founded on the waqf land from Mr H. Muhammad Yasin, established on May 20, 1989. In 2008/2009 it solidified its teachings according to the guidance of the Qur'an and As-Sunnah according to the understanding of the salaf al-ummah. The education units they manage are RA, SD, MTs, MA and STDIA.

Seventh, Pesantren Darush Shawab. It located in Kp. Babakan Ciawi, Nagasari, Serang Baru, Bekasi Regency, West Java Province. It was founded by KH. Ahmad Damiri. This pesantren serves the community by delivering Islamic education in several units.

Eighth, Pesantren Ashriyah type, At-Taqwa. It is located at Jalan Ujung Harapan, Babelan District, Bekasi Reency, West Java Province. This pesantren was founded by KH. Noer Ali (Alm) has 914 male students and 782 female students. Currently KH. Nurul Anwar, Lc leads the men's pesantren and KH. M. Amin Noer, MA leads the pesantren for girls.

Ninth, Pesantren Jamiyyah Islamiyyah which was founded by (Alm.) KH. M. Amin Syarbini. It islocated at Jl. Pesantren RT/RW: 03/03 Kp. Ceger, Jurangmangu, Jurang Mangu Timur, Pondok Aren Subdistrict, South Tangerang Banten 15222. This institution is led by KH. Zainuddin Abdullah. It has several education units including MTs, MA and Tahfizh alQur'an program.

Those pesantren institutions were involved in this study. They had one thing in common as Islamic educational institutions that serve to teach students Islamic knowledge and build their character to be Muslim who are required to worship their God and build good relationship with human. Those institutions are located in West java province and are to some extent closer to the capital city of Jakarta. They applied methods to teach Islamic knowledge to their students. In the next section, teaching methods applied in the pesantren to tackle religious radicalism will be elaborated.

\section{Teaching Methods Applied in Pesantren to Tackle Religious Radicalism}

Based on the data collected, this study found several teaching methods applied in those pesantren institutions. They applied several teaching methods and they expected that the methods administered were able to tackle religious radicalism. To tackle religious radicalism, each pesantren applied different method. Table 1 illustrate a big picture about teaching methods applied in those pesantren institutions.

Table 1. Teaching methods applied in each pesantren institution

\begin{tabular}{|c|c|c|c|}
\hline Pesantren & Learning Method & Orientation & Activities \\
\hline Darul Muttaqin & Cooperative & $\begin{array}{l}\text { - Developing } \\
\text { students' } \\
\text { social skills } \\
\text { - Giving } \\
\text { penalties } \\
\text { using a point } \\
\text { system } \\
\end{array}$ & $\begin{array}{l}\text { Fath al-Kutub: } \\
\text { - Can increase creativity and } \\
\text { cooperation between students } \\
\text { - Can encourage respect for the } \\
\text { opinions of others to tackle religious } \\
\text { radicalism in students }\end{array}$ \\
\hline & Teaching Methods & - Scouting & $\begin{array}{l}\text { Students will become Indonesian } \\
\text { citizens with the spirit of Pancasila and } \\
\text { later will guard the country and become } \\
\text { good and useful members of society, } \\
\text { capable and able to carry out nation and } \\
\text { state development. this well }\end{array}$ \\
\hline al-Karimiyyah & & $\begin{array}{lr}\text { Giving } & \text { penalties } \\
\text { using a point } \\
\text { system }\end{array}$ & $\begin{array}{l}\text { Always socializes the love of the } \\
\text { motherland to its students. That this } \\
\text { nation must be guarded in a good } \\
\text { manner, not by violence. }\end{array}$ \\
\hline
\end{tabular}




\begin{tabular}{|c|c|c|c|}
\hline Assalamah & & $\begin{array}{l}\text { - Sorogan and } \\
\text { bandongan or } \\
\text { halaqah } \\
\text { methods and } \\
\text { uses dialogue } \\
\text { or } \\
\text { deliberation } \\
\text { methods in } \\
\text { learning } \\
\text { The } \\
\text { curriculum } \\
\text { used } \\
\text { combination } \\
\text { of salafiyah } \\
\text { and modern }\end{array}$ & $\begin{array}{l}\text { - Pesantren visit by member of TNI } \\
\text { and POLRI was scheduled to } \\
\text { provide counselling for students } \\
\text { about the dangers of religious } \\
\text { radicalism } \\
\text { - Selection of every prospective } \\
\text { teacher who enrolled to pesantren to } \\
\text { ensure that they did not bring radical } \\
\text { ideas. } \\
\text { The teacher council also monitored } \\
\text { students' reading books which are } \\
\text { indicated as radical. }\end{array}$ \\
\hline Asy-Syahidiyah & & $\begin{array}{l}\text { Combined the } \\
\text { modern and } \\
\text { classic cottage } \\
\text { system. }\end{array}$ & $\begin{array}{l}\text { - Used an integrated curriculum, as it } \\
\text { contains a mix of modern and classic } \\
\text { methods } \\
\text { - The main jurisprudence is Shi'a, but } \\
\text { it is taught by other jurisprudence, } \\
\text { such as Maliki, Hambali, and Hanafi. } \\
\text { - Teaching subject, uses Islamic and } \\
\text { Maturidiyah beliefs. } \\
\text { - Tolerance is taught by cultivating the } \\
\text { doctrines of Tawasut, Tawazun, } \\
\text { Ta'adul and Tasamuh. } \\
\text { To address the dangers of religious } \\
\text { radicalism is being held in the field, } \\
\text { the construction of cadres by the } \\
\text { builders within the pesantren and in } \\
\text { cooperation with Islamic } \\
\text { organizations such as IPNU/ } \\
\text { IPPNU, ANSOR, NU, and others. } \\
\text { Student builders and leaders often } \\
\text { harass students from possible } \\
\text { symptoms of religious radicalism. }\end{array}$ \\
\hline Al-Hassan & $\begin{array}{l}\text { - Used classical } \\
\text { methods } \\
\text { - Discussion } \\
\text { - Question and } \\
\text { answer section }\end{array}$ & & $\begin{array}{l}\text { - Islamic material consists of aqeeda, } \\
\text { shari'a, morals, and Islamic scientific } \\
\text { and spiritual traditions. } \\
\text { - Indonesian material consists of } \\
\text { Pancasila and the } 1945 \text { Constitution, } \\
\text { Law No. } 20 \text { th. } 2003 \text {, and related } \\
\text { laws and regulations. }\end{array}$ \\
\hline Hidayatunnajah & $\begin{array}{l}\text { - Classical } \\
\text { method } \\
\text { - Deliberation } \\
\text { program } \\
\text { intended for } \\
\text { students. }\end{array}$ & $\begin{array}{l}\text { The teacher } \\
\text { inserted material } \\
\text { about moderate } \\
\text { Islamic values in } \\
\text { his learning that } \\
\text { is far from being } \\
\text { radical. }\end{array}$ & $\begin{array}{l}\text { Tolerance is a global issue that is } \\
\text { emerging, it needs to be included in the } \\
\text { material and learning methods to } \\
\text { support the cadre of students as } \\
\text { preachers in the global environment. }\end{array}$ \\
\hline
\end{tabular}




\begin{tabular}{|c|c|c|}
\hline Darush Shawab & $\begin{array}{l}\text { - Used classical Curriculum salaf } \\
\text { methods } \\
\text { - Discussion } \\
\text { - Question and } \\
\text { answer section } \\
\end{array}$ & $\begin{array}{l}\text { The mythology and creed taught in } \\
\text { Pesantren Darush Shawab were the } \\
\text { Madzhab ablussunnah waljamaah and the } \\
\text { doctrine of tolerance was included in the } \\
\text { curriculum }\end{array}$ \\
\hline Jamiyyah & $\begin{array}{l}\text { - Classical } \\
\text { method } \\
\text { - Bandongan } \\
\text { - Memorization } \\
\text { - Deliberation } \\
\text { methods in } \\
\text { their learning }\end{array}$ & $\begin{array}{l}\text { - Taught 'aswaja' material that } \\
\text { embodied the principle of tolerance. } \\
\text { - Implemented this teaching of } \\
\text { tolerance through the student } \\
\text { organization (OSIS) and the Islamic } \\
\text { Pesantren Jamiyyah Student } \\
\text { Organization (OP3JI) at Pesantren. }\end{array}$ \\
\hline At-Taqwa & $\begin{array}{l}\text { - Classical } \\
\text { method } \\
\text { - Bandongan } \\
\text { - Memorization } \\
\text { - Deliberation } \\
\text { methods in } \\
\text { their learning }\end{array}$ & $\begin{array}{l}\text { - Responded to radicalism with } \\
\text { education and training for students } \\
\text { and the entire organization of } \\
\text { pesantren by monitoring them } \\
\text { constantly }\end{array}$ \\
\hline
\end{tabular}

Based on the data collected in this study, the eight pesantren in West Java used the education system that can be categorized into two types. First, the classical education featured elaborated curriculum (a combination of classic and modern curriculum). Second, classical education which maintains a classical educational system. These pesantren can be categorized as classical pesantren instituions that retained the old Islamic book references (turas). Speaking of religious education, these institutions have their influence which are unquestionable because they educate and spread Islamic teachings to the public (Wahyoetomo, 1997).

Without their existence, it is not easy for the society to access Islamic knowledge. However, the pesantren instituions in this study had modified their learning methods and strategies that were relevant to their santri characteristics. They should uphold the motto to maintain good old ways and to adopt and develop new ways that are better (Mahfudh, 1999). They have many options to tackle religious radicalism and one of them is to transform teaching methods to suit their students to tackle religious radicalism.

Pesantren are not immune in the context of the spread of religious radicalism, as well as an antidote to the understanding of radical Islamic religion. Based on previous studies conducted. Pesantren had the opportunity to turn into radical propagators. The indication could be seen from the emergence of several Islamic educational institutions that were promoted by several radical Islamic-community based organizations. The issue of radicalism which are closely linked to pesantren institutions has made the image of pesantren worse (Nuhrison, 2010). Another study has also reported on the potential of pesantren for radicalism (Jahroni, 2007). In addition, a study also reported how salafiyah influenced students' perception on radicalism (Taufiq \& Kholilur, n.d). This is not a positive circumstance for pesantren institutions in general. Bad image of pesantren as a source of radicalism might discourage pesantren to develop its existence in the society.

The vast majority of pesantren in Indonesia fall into the category of non-radical institutions. A study conducted by Ma'arif (2014) show that most pesantren institutions promoted the development of a peaceful culture. The implication of this research is that pesantren institutions are required to represent educational institutions that do not promote a culture of violence. The implementation of the pesantren program is also required to be 
oriented towards transformative religious understanding. This can be seen from the orientation and learning methods applied in pesantren schools.

The learning method that has been administered in the eight pesantren institutions in West Java had met the criteria stated by Edgar Bruce Wesley's theory. The theory states that the teaching method is a series of activities directed by the teacher to tailor learning process which is convenient for students. It also implies that a process whose implementation is perfect to produce a learning process, or is a way by which teaching becomes memorable on the part of students (Nizar \& Hasibuan, 2011). A teaching method used by teachers in Indonesia should establish relationships between teacher and students during the learning process (Ramayulis, 2008).

Pesantren in this study had implemented several learning methods to implement learning plans in the form of practical activities. In general, they applied cooperative learning. This cooperative learning method was designed to develop academic learning outcomes and to nurture students' social skills. Pesantren Darul Muttaqien had organized fath al kutub (Islamic traditional book reading comprehension). The practical learning activities were oriented towards studying classic books (at-turäs) which are the main references for Islamic studies. This learning method is one of the group learning methods that can enhance creativity and cooperation between students and encourage them to respect and respect the opinions of others. Radical understanding of religion can be solved by using this method.

In other pesantren institutions, learning methods used was punishment by using a point system. This learning method was oriented to avoid violence in the provision of punishment. Punishment in the context of education and learning must be educational in nature. The method of punishment was applied at Pesantren Darul Muattaqien and Pesantren AlKarimiyah. In implementing this method, each student was given 100 points as a starting point. If students had no points left, their parent were immediately invited to pesantren. If they violated again they could be excluded from pesasntren. All eight pesantren instituions in this study had no longer resorted to violence acts such as slapping punishments on students to respect their human rights. The maximum penalty for students was to send them $\mathrm{r}$ to parents. Prior to this level of punishment, they were punished by cutting their hair into bald and punish them to stay under the sun. Sorogan and bandongan or halaqah methods and dialogue or deliberation methods were still used in those pesantren institutions. By using those teaching methods, students were expected to tackle religious radicalism.

The pesantren institutions also, in part, retained bandongan, sorogan and memorization methods. However, the classical learning methods were elaborated by explaining the material inclusively. The application of this learning method was also carried out in regions in Central Java according to the study conducted by Ramadhan (2015) like Pesantren Al-Hikmah, Pesantren Benda, Brebes. Pesantren Al-Hikmah and Amsilati were traditional pesantren institutions which in their learning promoted inclusivism. These pesantren also introduced multiculturalism through the method of habituation and example. It reported that in order to prevent radicalism in pesantren, learning should be carried out through field practice. The students live in with the community for three days and three nights and the program were conducted regularly. This program succeeded in minimizing radicalism understandings among the santri.

Based on the findings of this study, pesantren institutions are generally divided into two, classical and non-classical. These pesantren institions applied various Islamic traditional books and they were combined with modern lessons (national curriculum). This requires a combination of methods, not single methods so that students are provided with a variety of non-monolithic knowledge. According to (Irsyadunnas, 2018) Pesantren Darul Wahyain in Magetan, Central Java applied this combination system. This boarding school is a modern- 
classical combination boarding school that applied the mularamah learning system (classical) by studying various books from various schools of thought. Learning by introducing various schools of thought could minimize.

This study found that pesantren institions had employed teaching methods that were considered appropriate to tackle religious radicalism. This finding is in line with the previous studies conducted by researchers. Studies have reported the effort and program applied by pesantren to fight radicalism (Alfanani, 2017; Bahri, 2018). Other researchers have also investigated pesantren effort to fight radicalism in several regions: Pesantren in Lampung (Budi \& Chintya, 2017) Pesantren in Mojokerto (Laksono, 2017). In Kediri (Ferdian \& Mustofa, 2019); and in northern coast area of Java (Ridlwan, 2019). They have one thing in common in reporting effort of pesantren to tackle religious radicalism.

In addition to teaching methods applied in pesantren, multicultural education needs to be applied in pesantren education. This may serve as an effort to provide understanding to students that they must be respectful of each different beliefs and even each cultural character with each other in order to create a harmonious atmosphere and tolerance in the education system in Indonesia (Hamdani, 2005). This need to be nurtured and students are required to be trained on multicultural education so they can achieve the level and skill of multicultural understanding.

\section{CONCLUSION}

This study was aimed at investigating teaching methods applied in pesantren to tackle religious radicalism. It investigated several pesantren institutitons in West Java. It also explored the way teaching method applied in the pesantren. Based on the findings and analysis of this study, some conclusion can be drawn.

This study found that pesantren institutions have their effort to tackle religious radicalism. There were many methods applied by pesantren. Those methods include: cooperative learning or teaching methods designed to educate group cooperation. This teaching method is designed to achieve academic learning achievement. In addition, this teaching method was also effective for developing students' social skills. It was expected that they were able to respect for the opinions of others and discourage the culture of violence. This effort can be viewed as a best way to tackle religious radicalism among students in pesantren institutions.

Some suggestions are made for several parties. Teachers should master the comparative sciences and to continue practice using cooperative learning methods to develop students' social skills and encourage to the respect the opinions of others so that it becomes a powerful way of tackling religious radicalism in students. The leaders of pesantren should focus on the standard process including the socialization of the objectives and curriculum of the pesantren, holding regular teacher training on cooperative teaching methods to combat religious radicalism. The Government of the Republic of Indonesia should focus on improving the teaching profession by providing adequate budget allocations for teacher training related to cooperative teaching methods in combating religious radicalism.

\section{BIBLIOGRAPHY}

Alfanani, T. S. (2017). Konstruksi Sosial Komunitas Pesantren mengenai Isu Radikalisme (Studi Kasus pada Pesantren Salaf \& Modern di Kota Malang). Jurnal Sosiologi Agama, 10(2), 1-24.

Azra, A. (2002). Konflik Baru Antar Peradaban: Globalisasi, Radikalisme \& Pluralitas. Divisi Buku Perguruan Tinggi, RajaGrafindo Perkasa. 
Azra, A., \& Al-Jauhari, A. (1996). Pergolakan politik Islam: Dari Fundamentalisme, Modernisme hingga Post-Modernisme. Paramadina.

Bahri, S. (2018). Peran Pondok Pesantren dalam Mencegah Paham Radikalisme di Kabupaten Rejang Lebong. KAGANGA: Jurnal Pendidikan Sejarah dan Riset Sosial-Humaniora, 1(2), 107-121.

Budi, P., \& Chintya, A. (2017). Peran Pondok Pesantren dalam Deradikalisasi Paham dan Gerakan Islam Radikal (Studi pada Pondok Pesantren Riyadlatul Ulum 39 B Batanghari Lampung Timur). Fikri: Jurnal Kajian Agama, Sosial dan Budaya, 2(2), 284-306.

Cumming-McCann, A. (2003). Multicultural education: Connecting theory to practice. Focus on Basics, 6(2), 9-12.

Dhofier, Z. (1983). Tradisi Pesantren. LP3ES.

Ferdian, F., \& Mustofa, B. (2019). Strategi Pondok Pesantren Al Ma'ruf Kediri dalam Mencegah Paham Radikalisme Agama. Tribakti, 30(2), 362-371.

Fitriani, V., \& Sundawa, D. (2016). Penerapan Model Vct (Value Clarification Technique) dengan Menggunakan Media Cerita Daerah dalam Pembelajaran Pendidikan Kewarganegaraan untuk Meningkatkan Karakter Peserta Didik. Jurnal Pendidikan Imu Sosial, 25(1), 41-57. https://doi.org/10.17509/jpis.v25i1.3669

Irsyadunnas, I. (2018). Radikalisme Pesantren: Studi terhadap Pesantren Darul Wahyain Magetan. Jurnal Ilmiah Ilmu Ushuluddin, 17(1), 16-29.

Jahroni, J. (2007). Kemungkinan Munculnya Paham Islam Radikal di "Pondok Pesantren" Edi Susanto Wacana Gerakan Radikalisme Islam sejak Era Reformasi. Tadris, 2(1), 1-19.

Laksono, P. (2017). Peran Pesantren dalam Mencegah Fundamentalisme-Radikalisme Agama (Studi Kualitatif di Pesantren Nurul Ummah Desa Kembang Belor Kecamatan Pacet Kabupaten Mojokerto). AsketiK, 1(2).

Ma'arif, S. (2014). Ideologi Pesantren Salaf: Deradikalisasi Agama dan Budaya Damai. IBDA: Jurnal Kajian Islam dan Budaya, 12(2), 198-209.

Hamdani, M. D. al-. (2005). Introduksi Kurikulum Pendidikan Multikulturalisme di Islamic Boarding School. Jurnal Tajdid, 18(12).

Mahfudh, M. S. (1999). Pesantren Mencari Makna. Pustaka Ciganjur.

Malik, A., Sudrajat, A., \& Hanum, F. (2016). Kultur Pendidikan Pesantren dan Radikalisme. Jurnal Pembangunan Pendidikan: Fondasi dan Aplikasi, 4(2), 103-114.

Mastuhu. (1994). Dinamika Sistem Pendidikan Pesantren Cet. I. Jakarta: Inis.

Mursalin, A., \& Katsir, I. (2010). Pola Pendidikan Keagamaan Pesantren dan Radikalisme: Studi Kasus Pesantren-pesantren di Provinsi Jambi. Kontekstualita: Jurnal Penelitian Sosial Keagamaan, 25(2).

Nata, A. (2000). Ilmu Pendidikan Islam. Kencana Prenada Media Group.

Nizar, S., \& Hasibuan, Z. E. (2011a). Hadits Tarbawi (1 ed.). Kalam Mulia.

Nizar, S., \& Hasibuan, Z. E. (2011b). Hadits Tarbawi (1 ed.). Kalam Mulia.

Nuhrison, M. N. (2010). Peranan Islamic Boarding School dalam Mengembangkan Budaya Damai. Badan Litbang dan Diklat Kementerian Agama.

Poerwadarminta, W. J. S. (2002). Kamus Besar Bahasa Indonesia. Jakarta: Balai Pustaka.

Purwaningrum, A. Y. (2019). MALL as an Alternative Learning Strategy to Solve Students' Problems in Writing Recount Text. Eleventh Conference on Applied Linguistics (CONAPLIN 2018).

Qarḍāwī, Y. al-. (2003). Al-Shabwah al-Islāmiyah bayn al-jubud wa at-Tatarruf (1 ed.). Daar alSyuruq.

Ramadhan, M. (2015). Deradikalisasi Agama melalui Pendidikan Multikultural dan Inklusivisme (Studi pada Pesantren al-Hikmah Benda Sirampog Brebes). Jurnal SMART (Studi Masyarakat, Religi, dan Tradisi), 1(2). 
Ramayulis. (2008a). Metodologi Pendidikan Islam. Kalam Mulia.

Ramayulis. (2008b). Metodologi Pendidikan Islam. Kalam Mulia.

Ridlwan, M. (2019). Dialektika Pesantren dan Radikalisme di Pesisir Utara Lamongan. Jurnal Darussalam: Jurnal Pendidikan, Komunikasi dan Pemikiran Hukum Islam, 11(1), 36-55.

Sukardi. (2003). Metode Penelitian Pendidikan, Kompetensi dan Prakteknya. Bumi Aksara.

Taufiq, A., \& Kholilur, R. (n.d). Pengaruh Tingkat Salafiyah terhadap Perspektif Santri tentang Radikalisme di Pondok Pesantren Al Faqih. Politika: Jurnal Imu Politik, 2(2), 31-38.

Wahyoetomo, D. (1997). Perguruan Tinggi Pesantren, Pendidikan Alternatif Masa Depan Jakarta. Gema Insani Press. 